\title{
THE ATTORNEY'S DUTY TO REVEAL A CLIENT'S INTENDED FUTURE CRIMINAL CONDUCT
}

"I'm going to kill the guy who got me in this mess." An attorney who hears a client make such a statement faces a difficult dilemma. If he beheves that the client intends to commit the crime, the attorney can inform the pohice or the intended victim, or he can remain silent.

Unfortunately, current standards of professional responsibility provide equivocal guidance for attorneys facing such a decision. ${ }^{1}$ In fact, when the American Bar Association recently moved to replace the Model Code of Professional Responsibility (Code) ${ }^{2}$ witl new Model Rules of Professional Conduct (Rules), ${ }^{3}$ much debate focused on the

1. The standards may be unclear, but the literature on the subject of professional responsibility is voluminous. In the last few years, the number of publications has risen dramatically. For two diverse and broad views of the field, compare M. FreEdMan, LaWYers' Ethics in an Adversary System (1975) with G. Hazard, Ethics in the Practice of LaW (1978).

2. Model Code of Professional Responsibility (1979) [hcreinafter cited as Code].

3. Model Rules of Professional Conduct, reprinted in 68 A.B.A. J. 1411 (1982) [heremafter cited as RULES].

The rules were drafted by the Kutak Cornmission, a special commission created in 1977, named after its now-deceased chairman. See Kutak, Chairman's Introduction to RuLES (Proposed Final Draft 1981), reprinted in 67 A.B.A. J. 1229 (1981). In January, 1980 the Commission issued a discussion draft of the Rules. RuLes (Discussion Draft 1980). It published the discussion draft with the express purpose of eliciting comments. See Kutak, Chairman's Introduction to Rules (Discussion Draft 1980). The Commission was not disappointed; it was deluged with comments, see Kutak, Chairman's Introduction, to Rules (Proposed Final Draft 1981), and periodicals were filled with critiques of the discussion draft. See, e.g., Review Symposium: The Model Rules of Professional Conduct 1980 Am. B. Found. ReseARCH J. 921 (1980).

After examining the response to the discussion draft, the Commission published a proposed final draft in 1981. RuLes (Proposed Final Draft 1981). In subsequent meetings of the ABA's House of Delegates the Rules were debated and amended. In August, 1983 the House of Delegates finally approved the amended final draft. Rules (1983). See A.B.A. ANNUAL REPORT 1982-1983 13 (1983), reprinted in 70 A.B.A. J. 67 (1984). See generally Clark, Fear and Loathing in New Orleans: the Sorry Fate of the Kutak Commission's Rules, 17 Suffolk U.L. Rev. 79, 86 (1983).

To become binding in a particular state the Rules must be adopted by either the state legislature or the highest state court. See White, Why Did the Antitrust Division Dismiss the Case?, 64 A.B.A. J. 1667, 1669 (1978).

Regulation of professional ethics has a long history. In 204 B.C. a Roman statute, lex Cincia, forbade anyone from accepting money or gifts for pleading a case. See R. POUND, THE LAWYER 
issue of confidentiality. ${ }^{4}$ During these debates, questions concerning an attorney's duty to reveal his client's intent to commit a criminal act caused particular problems. ${ }^{5}$

This note analyzes the current ethical standards that guide an attorney when he thinks his client intends to commit a crime. ${ }^{6}$ It examines the alternate formulations of the ethical rules found in the various drafts of the new Rules. ${ }^{7}$ The note then explores the legal foundations of the attorney's duty to protect client confidences and the arguments supporting this duty ${ }^{8}$ The note concludes that the best rule is one that gives the attorney a considerable amount of discretion to determine what revelations he sliould make. ${ }^{9}$

FROM ANTIQUiTY to MODERN Times 52 (1953). Professor Drinker suggests that the first English attempt to regulate attorneys occured in 1275. H. DRINKER, LEGAL ETHICs 14-15 (1953); see also Pickholz, The Proposed Model Rules of Professional Conduct-and Other Assaults Upon the Attorney-Client Relationship: Does "Serving the Public Interest" Disserve the Public Interest?, 36 Bus. LAW 1841, 1842 (1981).

Tlie first formulation of a code of ethics occurred in 1836 when David Hoffman published lis A Course Of Legal Study Addressed to Students and the Professional Generally. See Kalish, David Hoffman's Essay on Professional Deportment and the Current Legal Ethics Debate, 61 NEB. L. REv. 54 (1982). Alabama adopted the first formal code of ethics in 1887. See generally Armstrong, $A$ Century of Legal Ethics, 64 A.B.A. J. 1063, 1063 (1979) (history of legal ethics). In 1908, the A.B.A. first adopted its Canons of Professional Responsibihity. See H. Drinker, Legal Ethics app. C n.I (1953); see also Canons of Professional Ethics (1908). The Code replaced the Canons in 1969.

4. Confidentiality was not the only area of controversy. For example, the discussion draft's proposal that all attorneys had an obhgation to provide legal services to the poor elicited a considerable amount of debate. See, e.g., Humbach, Serving the Public Interest: An Overstated Objective, 65 A.B.A. J. 564 (1979); Rosenfeld, Mandatory Pro Bono: Historical and Constitutional Perspectives, 2 CARdozo L. Rev. 255 (1981).

5. Confidentiality raised other issues too. The duty of an attorney to a corporate client and the duty of an attorney who knows of his client's perjury were two otlier highly controversial issues. See generally Abramovsky, Confidentiality: The Future Crime-Contraband Dilemmas, 85 W. VA. L. REV. 929, 937-40 (1983) (discussion of attorney's duty regarding incriminating evidence); Crystal, Confidentiality Under the Model Rules of Professional Conduct, $30 \mathrm{KAN}$. L. REv. 215 (1982) (general discussion of confidentiality issues); Erickson, The Perjurious Defendant: $A$ Proposed Solution to the Defense Lawyer's Conflicting Ethical Obligations to the Court and to His Client, 59 DEN. L.J. 75 (1981) (problems of confidentiality when client perjures himself); Leiman, Responsibility to Report Securities Law Violations 6 INST. ON SEC. REG. (PLI) 265 (1975) (discussion of attorney's duty regarding corporate clients and the SEC); Robins, Policeman, Conscience or Confidant: Thoughts on the Appropriate Response of a Securities Attorney Who Suspects Client Violations of the Federal Securities Laws, IS J. MAR. L. REV. 373 (1982); Note, Ethics, Law, and Loyalty: The Attorney's Duty to Turn Over Incriminating Physical Evidence, 32 STAN. L. ReV. 977 (1980). These issues are outside the scope of this note.

6. Sce infra notes 10-25 and accompanying text. The discussion is limited to noncorporate crimes and does not attempt to examme the crime of perjury.

7. See infra text accoinpanying notes $26-45$.

8. See infra text accompanying notes 48-79.

9. See infra text accompanying notes $80-90$. 


\section{Formulations of the Attorney/Client Confidentiality RULE}

\section{A. The Model Code of Professional Responsibility.}

Currently, the Model Code of Professional Responsibility guides attorneys in matters of professional responsibility. ${ }^{10}$ The Code contains three types of guidelines: Canons, Ethical Considerations, and Disciplinary Rules (DRs). Canons merely state general ethical rules; ${ }^{11}$ Ethical Considerations are "aspirational in character and represent the objectives" toward which lawyers should strive. ${ }^{12}$ Disciplinary Rules define the minimum standards of professional conduct. Thus, if an attorney's conduct does not conform to the Disciplinary Rules, he may be subject to disciplinary action. ${ }^{13}$

Canon Four of the Code urges that "A Lawyer Should Preserve the Confidences and Secrets of a Client."14 DR 4-101(B) embodies much of Canon Four:

[A] lawyer shall not knowingly: (1) Reveal a confidence or secret of his chent. (2) Use a confidence or secret of his client to the disadvantage of the client. (3) Use a confidence or secret of his client for the advantage of himself or of a third person, unless the client consents after full disclosure. ${ }^{15}$

DR 4-101(C)(3), however, provides that a lawyer may reveal the "intention of his client to commit a crime and the imformation necessary to prevent the crime." 16

Unfortunately, it is not clear whether the current Disciplimary Rule imposes any obligation on an attorney to reveal that his client intends to commit a crime. It says only that the attorney "may" reveal his client's intent. ${ }^{17} \mathrm{~A}$ footnote suggests that the attorney might be obliged to reveal his client's criminal plans in certain situations. ${ }^{18}$ The

10. At least 42 states have adopted or approved the Code of Professional Responsibility. See Kramer, Clients' Frauds and Their Lawyers' Obligations: A Study in Professional Irresponsibility, 67 GEO. L.J. 991, 994 \& n.20 (1979); cf. Merton, Confidentiality and the "Dangerous" Patient: Implications of Tarasoff for Psychiatrists and Lawyers, 31 EMORY L.J. 275, 276 n.24 (the Code has been adopted in some form, albeit with significant deletions and modifications, by every state and the District of Columbia). Different authors apparently have differing criteria as to whether the Code has been adopted.

11. The Canons are "axiomatic norms, expressing in general terms the standards of professional conduct expected of lawyers." CoDE, supra note 2, Preliminary Statement 3, 4 (1979).

12. Id.

13. Id.

14. Id. Canon 4.

15. Id. DR 4-101(B) (footnotes omitted).

16. Id. DR 4-101(C)(3) (footnotes omitted).

17. Id.

18. Id. Canon 4 n.16 (quotimg ABA Comm. on Professional Ethics, Formal Op. 314 (1965)). 
footnote quotes an opinion of the Committee on Professional Ethics of the American Bar Association 19 for the proposition that if "the facts in the attorney's possession indicate beyond reasonable doubt that a crime will be committed," the attorney has a duty of disclosure. ${ }^{20}$ Thus, the footnote purports to create a mandatory duty to disclose a client's intent to commit a crime if the facts in the attorney's possession indicate beyond reasonable doubt that a crime will be committed.

Two factors suggest, however, that the footnote is not definitive. First, footnotes to the Code are "intended merely to enable the reader to relate the provisions of [the] code to the ABA Canons of Professional Ethics adopted in 1908."21 The Code's drafters did not intend the footnotes to be definitive interpretations of the Disciplinary Rules; the footnotes are merely meant to help explain thein. Second, the passage quoted in the footnote is clearly dictum in the committee's opinion. ${ }^{22}$

Nevertheless, soine commentators argue that DR 4-101 creates a duty for attorneys to reveal certain crimes their clients intend to commit. ${ }^{23}$ Others deny that any such obligation exists. ${ }^{24}$ This note will

19. The opinions of the Committee are its expressions concerning proper professional conduct. Opinions are given after a question is raised by a member of the bar. DrINkER, supra note 3 , at 31 .

20. CODE, supra note 2, Canon 4 n.16.

21. Id. Preamble n.1.

22. ABA Comm. on Professional Ethics, Formal Op. 314 (1965) (with respect to practice before the IRS, a lawyer is under no duty to reveal the weaknesses of his client's case); see also Leiman, supra note 5, at 267-68 ("That is an obscure note, set im very small type. It seems to me to be such an oblique way to modify the large, black letter rule that I doubt Note 16 creates a separate duty.").

Other opinions of the Ethics Committee are similarly confusing. See ABA Comm. on Professional Ethics and Grievances, Formal Op. 287 (1953) (attorney should not inform court of client's perjury and attorney has no duty to correct court when it imposes sentence based on misinformation); ABA Comm. on Professional Ethics and Grievances, Formal Op. 155 (1936) (attorney inust reveal whereabouts of client who jumps bail); ABA Coinm. on Professional Ethics and Grievances, Formal Op. 23 (1930) (attorney should not reveal fugitive client's whereabouts).

Other ABA materials suggest that there is a duty to disclose. See e.g., ABA SEction ON Criminal Justice, Standards Relating to the Administration of Criminal Justice, Standard 4-3.7(d) (2d ed. 1980) (lawyer must reveal expressed intention of client to commit crime and information required to prevent crime where the crime would seriously endanger life or safety of person or corrupt processes of courts). The ABA standards are not the law of any jurisdiction and are not enforced.

23. '[O]ne wouldn't question the lawyer's obligation if the situation were one where a hazardous drug is let loose on the public [by the client]. It would plainly be a lawyer's duty to report the situation to authorities who could prevent the drug from damaging the public users." Leiman, supra note 5, at 273.

24. "Outside the tax area, the business practitioner is under no duty to disclose client misconduct . . . ." Robins, supra note 5, at 422. "It is notewortlyy that no federal administrative agency other than the SEC has adopted, proposed or even informally advocated imposing upon laywers obligations similar to those proposed by the SEC." Lipman, The SEC's Reluctant Police Force: $A$ New Role for Lawyers, 49 N.Y.U. L. REv. 437, 476 (1974). 
explore these arguments more fully below. ${ }^{25}$

\section{B. Model Rules of Professional Conduct.}

The Model Rules of Professional Conduct went through several drafts before the American Bar Association finally adopted them in 1983.26 All of the drafts required attorneys to protect client confidences in the same general way. The initial discussion draft provided that:

In giving testimony or providing evidence concerning a client's affairs, a lawyer shall not disclose information concerning the client except as authorized by the applicable law of evidentiary privilege. In other circumstances, a lawyer shall not disclose information about a client which relates to the client-lawyer relationship, which would embarrass the client, which is likely to be detrimental to the client, or which the client has requested not be disclosed . . . .77

Callan and David believe that no law requires an attorney to disclose client misconduct: Crimmal offenses such as aiding and abetting a crime, obstruction of justice, misprision of a felony, or becoming an accessory after the fact arguably might be applied to attorneys for failure to disclose their clients' criminal misconduct. Such an application, however, would be wholly mappropriate since it would conflict with attorneys' legal duty of confldentiahty deriving froin the attorney-client privilege . . . and would impermissibly interfere with their clients' exercise of the privilege agaimst self incrimination. These principles are basic to our system of justice, and the duty of silence which they mandate cannot logically be considered an obstruction of justice or conduct which aids the commission of a crime or fraud.

Callan \& David, Professional Responsibility and the Duty of Confidentiality: Disclosture of Client Misconduct in an Adversary System, 29 Rutgers L. REv. 332, 357 n.109 (1976); see also infra notes 48-54 and accompanying text; Note, Functional Overlap Between the Lawyer and Other Professionals: Its Implications for the Privileged Communications Doctrine, 71 YALE L.J. 1226, 1244 (1962) (generally the attorney has no duty to coine forward).

25. See infra note 82 and accompanying text.

26. See supra note 3. The Ainerican Trial Lawyers Association also forınulated a code of conduct. See The Roscoe Pound-American Trial Lawyers Foundation Commission on Professional Responsibility, AMERICAN LAWYER's CODE of Conduct (Discussion Draft 1980). While discussing the ABA Rules, the introduction to their code states: "The proponents of an alternative to this Code have apparently forgotten that [our system of justice is an adversary one]. Their most recent draft would erode basic constitutional protections by making the lawyer the agent of the state, not the champion of the client, in many inportant respects." Introduction, to id. at iii.

The Foundation was unable to agree on the circumstances in which disclosure of client confldences would be appropriate. See The Client's Trust and Confidences, Comment in id. at 105. Consequently, the Foundation published two alternative provisions. One version provides: "A lawyer may reveal a client's confldence when the lawyer reasonably believes that divulgence is necessary to prevent imminent danger to human hfe. In such a case, the lawyer shall use all reasonable means to protect the chent's interests, consistent with preventing loss of life." Id., Rule 1.4, Alternative $A$. The most significant variation found in the second version of the Foundation's confidentiality rule is the lack of a provision similar to the one just quoted. Id., Rule 1.4, Alternative B. That is, Alternative B contams no provision for revealing intended client wrongdoing.

27. Rules, supra note 3, Rule 1.7 (Discnssion Draft 1980). Later drafts simplifled the language of the rule: "A lawyer sliall not reveal information relating to the representation of a client except as [otherwise provided], unless the client consents after disclosure." Id., Rule 1.6 (Proposed Final Draft 1981). This broadens the scope of protected information. 
Several changes from the old Code are apparent in this new rule. The rule protects information relating to the representation that the attorney acquired before or after the professional relationship with the client was formed, regardless of how it was obtained; 28 the Code protected only "confidences and secrets" acquired from the client during the lawyer-client relationship. ${ }^{29}$ The rule also broadens the scope of protected information by changing what the lawyer is instructed not to reveal. "Confidences and secrets" 30 is a narrow formulation of protected material relative to the provision in the proposed final draft of the Rules that protects "information relating to the representation of a client."'31

The various drafts of the Rules differed in the extent to which they required that the attorney reveal what he knows. The initial discussion draft of the rule provided that: "A lawyer shall disclose information about a client to the extent it appears necessary to prevent the client from committing an act that would result in death or serious bodily harm to another person." 32 Thus, this draft mandated disclosure to prevent death or serious bodily harm. For disclosure to be mandatory under the initial discussion draft of the Rules, the act that would cause death or serious bodily harm did not have to be criminal, fraudulent, or in any way wrongful. ${ }^{33}$ This was a major change from the Code because, as noted above, ${ }^{34}$ the Code arguably did not mandate disclosure of intended acts of any kind. Later drafts of the rule returned to the Code's position and did not mandate revelation of any intended crimes. ${ }^{35}$

The various drafts of the Rules each provided exceptions to the general principle forbidding attorneys from disclosing confidential information about their clients. The drafts, however, varied considerably in the extent to which they excepted froin protected status an attorney's knowledge that lis client intended to commit a crime. Early drafts permitted revelation of less serious intended offenses; the later drafts protected nonserious crimes from revelation.

28. RULES, supra note 3, Rule 1.6 note (Proposed Final Draft 1981).

29. See id.; CODE, supra note 2, DR 4-101(A).

30. CODE, supra note 2, DR 4-10I(A) ("confidence" is material protected by lawyer-client privilege, whereas "secret" refers to information gained in the professional relationship whose disclosure would be embarrassing or detrimental to the client).

31. RuLes, supra note 3, Rule 1.6 (Proposed Final Draft 1981).

32. Id. Rule 1.7 (Discussion Draft 1980).

33. See id.

34. See supra notes $17-25$ and accompanying text.

35. RuLEs, supra note 3, Rule 1.6 (Proposed Final Draft 1981 \& Amended Final Draft 1982). 
Regarding less serious crimes, the discussion draft provided that a lawyer may disclose imformation about a client "[t]o the extent it appears necessary to prevent or rectify the consequences of a deliberately wrongful act by the client." 36 The Code had allowed an attorney to reveal his client's intent to commit a crime. ${ }^{37}$ The discussion draft of the Rules significantly broadened this authorization. It instructed the lawyer that he could reveal confidences in order to prevent or rectify a deliberate wrong. ${ }^{38}$ Because many wrongs are not crimimal, the discussion draft's reference to a "deliberate wrong" was a broader formulation than the Code's reference to "a crime." 39

The next draft of the Rules, the proposed final draft, made several substantive changes in the permissive-disclosure provisions of the Rules. With respect to serious crimes, rather than mandating an attorney to reveal a client's intent to commit any act when such revelation would prevent death or injury, the proposed final draft would have allowed the lawyer to reveal an intended act likely to result in death or bodily injury only when the client's intent was criminal or fraudulent. ${ }^{40}$ This change not only removed the obligation to reveal a client's intent to commit an act that might cause serious bodily mjury; it also forbade the attorney froin revealing a client's intent to commit an act that might cause bodily injury if that act were neither criminal nor fraudulent. ${ }^{41}$

With regard to less serious crimes, the proposed final draft limited the lawyer to revealing a criminal or fraudulent act likely to result in substantial injury to financial or property interests. ${ }^{42}$ Unlike the discussion draft, it did not permit an attorney to reveal that his client merely intended to commit a wrongful act. In order to be disclosable under the proposed final draft, a wrongful act liad to be criminal or fraudulent and cause serious financial or bodily harm.

The rule that the ABA ultimately adopted moved even further to-

36. Id. Rule 1.7 (Discussion Draft 1980) (the rule made it clear that a lawyer could not reveal to rectify a previous wrongful act when he was employed after the act to represent the client concerning the act).

37. CoDE, supra note 2, DR 4-101(B).

38. RULES, supra note 3, Rule 1.7 (Discussion Draft 1980).

39. A wrongful act is an act that violates a penal or civil standard in which knowledge of the circumstances is an element of the violation. RuLes, supra note 3, at 6 (Discussion Draft 1980). Although this change expanded the scope of protected information by allowing the revelation of nonpenal wrongs, it also narrowed the scope. The current code allows revelation of a crime. Arguably a strict hability crime is revealable; because knowledge is not an element of the violation of a strict liability crime, it is not considered to be a wrongful act. See Landesman, Confidentiality and the Lawyer-Client Relationship, 1980 UTAH L. REv. 765, 766 (1980).

40. RuLES, supra note 3, Rule 1.6 (Proposed Final Draft 1981).

41. See id.

42. $I d$. 
ward protecting client confidences; ${ }^{43}$ the lawyer may reveal information only to prevent the client from committing a criminal act likely to result in imminent deatli or substantial bodily liarm. ${ }^{44}$ The lawyer inay no longer reveal information only to prevent serious financial liarm. ${ }^{45}$

These final provisions are inuch narower than the Code's disclosure provisions. Under the Rules, the lawyer may not reveal that his client is going to commit an egregious crime unless that crime will result in deatlı or bodily injury. Like the Code, the Rules currently do not mandate any disclosure.

\section{The Basis for the Attorney's Duty of Confidentiality}

\section{A. Legal Basis of the Duty.}

Clearly, the current Code and the various drafts of the Rules do not agree on an attorney's responsibilities wlien confronted witl a client who intends to commit a crime. An analysis of the legal concepts that give rise to the attorney's duty of confidentiality deinonstrates that an attorney inay reveal a client's intended crime. The duty to protect client confidences lias two foundations. The first foundation of the duty is the attorney-client privilege from the rules of evidence. ${ }^{46}$ The second foundation for this responsibility derives from the fiduciary duty of an agent to his principal. 47

1. Attorney-Client Privilege. Scholars debate the history of the attorney-client privilege, ${ }^{48}$ but its outlines are well-settled. Wignore gave the classic definition of the privilege:

(1) Where legal advice of any kind is sought (2) from a professional legal advisor in his capacity as such, (3) the communications relating to that purpose, (4) made in confidence (5) by the client, (6) are at his instance permanently protected (7) froin disclosure by linuself or by the legal advisor, (8) except the privilege be waived. ${ }^{49}$

43. Id. (1983). See supra note 3.

44. Id., Rule 1.6 (1983).

45. Id.

46. See infra notes $48-54$ and accompanying text.

47. See infra notes 55-59 and accompanying text.

48. Compare 8 J. Wigmore, EvideNCE $\$ \S 2290-2291$ (McNaughton rev. ed. 1961) ("The history of this privilege goes back to the reign of Elizabeth, where the privilege already appears as unquestioned. . . . The policy of the privilege has been plainly grounded, since the latter part of the 1700s . . . .") with Hazard, An Historical Perspective on the Attorney-Client Privilege, $66 \mathrm{C}_{\mathrm{A}-}$ LIF. L. REv. 1061, 1070 (1978) ("[T]he historical foundations of the privilege are not as firm as the tenor of Wigmore's language suggests. On the contrary, recogmition of the privilege was slow and halting until after 1800.").

49. $8 \mathrm{~J}$. WIGMORE, supra note 48 , at $\$ 2292$ (footnote \& emphasis omitted); see also United States v. United Shoe Mach. Corp., 89 F. Supp. 357, 358-59 (D. Mass. 1950) (contains another widely-quoted definition of the privilege). 
Originally, the privilege belonged to the attorney who, as a gentleman, was obliged not to violate a pledge of secrecy. ${ }^{50}$ Modern theory has abandoned this position and now holds that the privilege belongs to the client. ${ }^{51}$ Because the privilege is the client's, not the attorney's, the attorney can not waive the privilege and disclose his client's secrets, even if he believes revelation is desirable.

Although the attorney may not choose to waive the privilege, the attorney-client privilege does not coinpletely protect a client's secrets. The privilege is strictly construed ${ }^{52}$ and does not apply to every transaction between attorney and client. ${ }^{53}$ In addition there is a "crimefraud" exception to the privilege. This exception removes protection from communications made for the purpose of furthering a crime or fraud. ${ }^{54}$ Therefore, most communications of the sort under discussion im this note are not protected. Nevertheless, the mere fact that information is not privileged does not impose a duty on the attorney to reveal that information.

2. An Agent's Responsibility to His Principal. Primciples of agency law may also limit an attorney's discretion to disclose client confidences. Because an attorney is an agent of his client, ${ }^{55}$ he has a fiduciary obligation to his" chent. 56 The fiduciary duty created by the attorney-client relationship obliges the attorney to hold inviolate his client's confidences. Unless they agree otherwise, an agent is subject to a duty to his primcipal not to use or communicate information confidentially given him by the primcipal or acquired by him during the course of his agency. ${ }^{57}$ The agent cannot use information im competition with, or to the detriment of, the primcipal, even though the infor-

50. See 8 J. WigmORE, supra note 48, at § 2290; see also United States v. Grand Jury Investigation, 401 F. Supp. 361, 369-70 (W.D. Pa. 1975) (citing Wigmore); In re Colton, 201 F. Supp. 13, 15 (S.D.N.Y. 1961) (citing Wigmore), affd sub nom. Colton v. United States 306 F. $2 \mathrm{~d} 633$ (2d Cir. 1962), cert. denied, 371 U.S. 951 (1963); see also Hazard, supra note 52, at 1070.

51. See, e.g., People v. Fentress, 103 Misc. 2d 179, 189, 425 N.Y.S.2d 485, 492 (Dutchess Cty. Ct. 1980).

52. See, e.g., United States v. Nixon, 418 U.S. 683, 710 (1974) ("whatever their origins, these [Fifth Amendment, attorney-client, and priest-penitent] exceptions to the demand for every man's evidence are not lightly created nor expansively construed, for they are in derogation of the search for truth").

53. See Garner v. Wolfinbarger, 430 F. 2d 1093, 1100-01 (5th Cir. 1970), cert denied sub. nom Garner v. First Amer. Life Ins. Co., 401 U.S. 974 (1971); 8 J. WIGMORE, supra note 48, at \& 2292.

54. See Grant, Attorney-Client Privilege and the Proposed Model Code of Professional Responsibility, 6 J. CRIM. Def. 163, 168 (1980); Hellerstein, Current Attorney-Client Privilege Issues, 4 ALI-ABA Course MATERIALS J. 5,7 (1979).

55. $8 \mathrm{~J}$. WIGMORE, supra note 48 , at $§ 2291$.

56. Id.

57. Restatement (SECOND) OF Agency $§ 395$ (1958). 
mation does not relate to the transaction in which he is then einployed, unless the information is a matter of general knowledge. 58

This rule of agency protects more material than does the attorneyclient privilege. For example, the attoney-client privilege applies only to a legal relationship; yet agency primciples limit an attorney even when he is not acting in his professional capacity. The attorney-chent privilege protects client confidences from mvoluntary revelation only in judicial proceedings; but agency law limits an attorney's abihity to reveal a client's secrets in other contexts as well.

As with the attorney-client privilege, however, there is an exception to the general rule requiring agents to preserve their principal's secrets. An agent is privileged to reveal information that he acquired in confidence in the course of his agency in order to protect a superior interest of his own or of a third person. Thus, if the agent knows that the principal is committing or is about to commit a crime, the agent is under no duty not to reveal what he knows. ${ }^{59}$ Although the agent is free to expose his principal's intended crime, agency law does not require the agent to do so.

\section{Potential Legal Limits on Maintaining Client Confidentiality.} A court might use other legal bases to creat a duty to reveal certain client confidences. In Tarasoff $v$. Regents of the University of California ${ }^{60}$ the California Supreme Court held that a psychiatrist has a duty under negligence primciples to protect the intended victim of a violent crime. Similarly, some commentators now beheve that the saine tort principles require a lawyer to warn of a client's imtent to commit a criminal act. ${ }^{61}$

The Tarasoff court held that: "When a therapist determines, or pursuant to the standards of his profession should deternime, that his patient presents a serious danger of violence to another, he incurs an obligation to use reasonable care to protect the intended victim against such danger."62 The court reasoned that the therapist-patient relationship is a special relationship that creates a duty to control a patient's conduct. 63 The court recognized the importance of confidentiality in

58. Id.

59. Id. $\S 395$ comment $\mathrm{f}$.

60. 17 Cal. 3d 425, 431, 551 P.2d 334, 340, 131 Cal. Rptr. 14, 20 (1976).

61. See generally Mcrton, supra note 10. One clear distinction between lawyers and psychiatrists is that lawyers have never suggested that they have the ability to detect a predilection for violence. See id. at 330. On the other hand, it is not as necessary for a client to tell a lawyer of his criminal intentions as it is for a patient to tell lis psychiatrist of lis criminal intentions.

62. Tarasoff, 17 Cal. 3d at 431, 551 P.2d at 340, 131 Cal. Rptr. at 20.

63. Id. at 436, 551 P.2d at 343, 131 Cal. Rptr. at 23. 
the therapist-patient relationship, but suggested that the duty to warn others might outweigh it. 64

The logic employed by the Tarasoff court could force lawyers to warn their client's intended victims. As noted above, an attorney's knowledge that a client is going to harm someone is not privileged. The lawyer-client relationship could be sufficiently special to justify imposing on the attorney the duty to control his client's actions. As in Tarasoff, the interest of the lawyer and his client in confidentiality may be outweighed by the public's need for safety.

In Hawkins $\nu$. King County Department of Rehabilitation Services, ${ }^{65}$ a lawyer was sued by the parents of his client's victim for failing to reveal, at a bail hearing, that his client was violently msane. The Washington Court of Appeals held that "the duty of counsel to be loyal to his client and to represent zealously his client's interest overrides the nebulous and unsupported theory that our rules and ethical code mandate disclosure of information which counsel considers detrimental to his client's stated interest." 66 The court, however, was "persuaded by the position advanced by annicus that the obligation to warn, when confidentiality would be compromised to the client's detriment, must be permissive at most, unless it appears beyond a reasonable doubt that the client has formed a firm intention to inflict serious personal injuries on a unknowing third person." "67 By inplication then, it is quite possible that with a different set of facts the Hawkins court would have recognized a duty to warn. This would create a duty on the part of atorneys to warn of their client's intended crimes. ${ }^{68}$

64. Id. at 440,551 P.2d at 346,131 Cal. Rptr. at 23.

65. 24 Wash. App. 338, 602 P.2d 361 (1979).

66. Id. at $343,602 \mathrm{P} .2 \mathrm{~d}$ at 365 . This is the only reported case against an attorney that has einployed reasoning similar to that in Tarasoff.

67. Id. at $344,602 \mathrm{P} .2 \mathrm{~d}$ at 365 . There was also a suggestion in dictum that a coinmon law duty to volunteer information to a court considering pretrial release inight exist if the attorney were convinced beyond a doubt that the chient was going to inflict injury on unknowing third persons. $I d$.

68. The Securities and Exchange Commission contends that attorneys have a duty to the public that entails disclosing a client's intended wrongs. See SEC v. National Student Marketing Corp., 457 F. Supp. 682, 713 (D.D.C. 1978) (Commission charged attorneys with failing to notify the Commission concerning the inisleading nature of financial statements to be issued by a client). See also In re Carter, 1981 Fed. Sec. L. Rep. (CCH) I 82,847 (SEC Release No. 34-17597). SEC Chairman Harold M. Williams has stated that he believes an attorney must reveal a corporate client's ongoing fraud. Williams, Corporate Accountability and the Lawyer's Role, 34 Bus. LAW REv. 7, 8 (1978). Because the Commission can bar an attorney from practicing before it through the use of section 5(e) of its rules of practice, 17 C.F.R. $\$ 201.5(\mathrm{e})$ (1983), its views are significant. 


\section{B. The Practical Bases for the Duty of Confidentiality.}

Neither agency nor evidence law forbids an attorney from revealing that his client intends to commit certain crimes. Yet agency law, evidence law, and professional codes of ethics do not currently require an attorney to reveal his client's intent to commit a crime. Numerous arguments have ben advanced in suport of an attorney's ethical obligation to maintain confidentiality. Proponents argue that confidentiality ensures effective assistance of counsel, ${ }^{69}$ fundamental fairness, ${ }^{70}$ and reduction of crime. ${ }^{71}$ They argue that the attorney-client relationship is extremely important and that any harm caused by the breach of the attorney-client relationship inust be outweighed by the benefits of the breach.

One rationale behind the rule of confidentiality is that a client, knowing his secrets are safe, will divulge information necessary for his lawyer to provide adequate representation and advice. ${ }^{72}$ If an attorney is to represent his client adequately, he should have full knowledge of the circumstances surrounding the client's questionable conduct. Often the client will not know how much of the information he possesses is relevant. Therefore, it is important that the client tell the attorney everything he knows. If the client screens the information he imparts to his attorney, because of worries about what the attorney must then disclose to proper authorities, he may screen out relevant inforination. The integrity of the adversary system depends on a client's faith in confidentiality and tlie attorney-client relationship.

Reducing the inviolability of an attorney-client confidence may also reduce the quality of legal advice given. ${ }^{73}$ If an attorney lias a duty to reveal intended crimes, he will be quite cautious in advising his client. If the attorney is afraid of incurring personal liability, he may

69. See infra notes $72-74$ and accompanying text.

70. See infra notes 75-79 and accompanying text.

71. See infra notes 78-79 and accoinpanying text.

72. See Ambramovsky, supra note 5, at 931 ("primary goal of the confidentiality doctrine is to ensure that a client may freely inform his lawyer of any and all pertinent facts and circumstances") (footnote omitted); Crystal, supra note 5, at 224 ("such rules foster an important social purpose by facilitating commumication between lawyers and clients"); see also People v. Belge, 83 Misc. 2d 186, 189, 372 N.Y.S. 2d 798, 801 (Onondaga Cty. Ct.) ("effectiveness of counsel is only as great as the confidentiality of its client-attorney relationship. If the lawyer cannot get all the facts about the case, he can only give his client half of a defense."), aff d, 50 A.D.2d 1088, 376 N.Y.S.2d 771 (1975) (per curiam).

73. ABA Section on Corporation, Banking and Busmess Law, Statement of Policy Adopted by American Bar Association Regarding Responsibilities and Liabilities of Lawyers Advising with Respect to the Compliance by Clients with Laws Administered by the Securities and Exchange Commission, 31 Bus. LAw, 543, 545 (1975) [heremafter cited as ABA Statement]. See Robins, supra note 5, at 413-15. 
advise his chent not to follow a likely legal, but nevertheless questionable, course of conduct in order to insure that he will not be subject to hability for failure to reveal the crime, if the conduct is indeed criminal. ${ }^{74}$

Another advantage of a strict confidentiahty rule is that it promotes a sense of fairness, at least among potential litigants. ${ }^{75}$ The legal justice system is complex.

People with legal problems need help; they often do not understand the complicated legal system in which they are enmeshed. Their sense of fairness . . . is enhanced when they need not fend for themselves ... . This simple and powerful ideal of legal representation is obviously sacrificed when a chent senses that his attorney's loyalties are divided. ${ }^{76}$

If the chent knows that his secrets are safe with his attorney his sense that the legal system will treat him fairly is enhanced. On the other hand, if the client believes that an attorney has a duty to reveal the client's secrets, his sense of fairness is dimmished. A chent who beheves that his attorney's loyalties are divided between the client and society im general, may feel that society has an unfair edge. "He told me to tell him everything, then he went and turned me $\mathrm{m}$," might be a chent's response to an attorney's disclosure of his secrets. If a client beheves that an attorney has not dealt fairly, confidence and trust in the legal system will surely diminish. An appearance of fairness gives the legal system legitimacy and should not be hightly sacrificed. ${ }^{77}$

74. "The client's actions sloould not be improperly narrowed through the insistence of an attorney who may, perhaps unconsciously, elimimate available choices from consideration because of his concern over possible personal risks if the position is taken which, though supportable, is subject to uncertainty or contrary to a known, but perhaps erroneous, position of the SEC or a questionable lower court decision." ABA Statement, supra note 73, at 545.

The rule of confidentiality has constitutional implications. A client has fifth- and sixthamendinent rights to effective assistance of counsel and a privilege against self-incrimination. U.S. CoNST. amends. V \& VI. It is thought that a lawyer must protect a client's secrets in order to provide effective assistance of counsel. If the attorney functions as a conduit for information from his client to the state, the client is forced to choose between effective assistance of counsel and incrimmating hinself through his attorney's revelations. See, e.g., Trainmel v. United States, 445 U.S. 40, 51 (1980) (dictum); see also Note, The Attorney-Client Privilege: Fixed Rules Balancing and Constitutional Entillement, 91 HARv. L. REv. 464, 485 (1977).

75. See generally Alschuler, The Preservation of a Client's Confidences: One Value Among Many or a Categorical Imperative?, 52 U. CoLO. L. REv. 349 (1981).

76. Id. at 351-52. Little is known about the extent of clients's knowledge about the attorneyclient privilege and how much faith they have that their attorneys will not reveal their secrets. One study found that 71 out of its 108 subjects believed that an attoruey would not revcal matters told to thein in confidence. 34 of the subjects believed that an attorney would not disclose a confidence even if ordered by a judge. Note, supra note 24, at 1062.

77. Fairness, as distinguished froin factual correctness, has long been an inportant concern of the American justice system. See, e.g., International Shoe Co. v. Washington, 326 U.S. 310,316 
Finally, the duty of confidentiality may actually reduce crime. ${ }^{78}$ If a client believes that his attorney will "turn him in" if he reveals his intent to commit a crime, then he likely will not reveal his plans to his attorney, depriving the attorney of an opportunity to inform the client of a lawful course of action that would accomphish the chent's desired end. A client who knows that his attorney will not reveal his intended crime is more likely to discuss the intended crime with the attorney who may persuade his client to follow a lawful course of action. ${ }^{79}$

\section{The Harms of a Mandatory Rule and the Benefits of DisClOSURE}

Although attorneys contmue to argue over what they ought to disclose and whether they should ever be required to disclose, ${ }^{80}$ few con-

(1945) (long-arm jurisdiction dependent upon "traditional notions of fair play and substantial justice").

78. See Leiman, supra note 5, at $276 \mathrm{n} .97$ (1975).

79. Other commentators deny that attorneys are able to convince their clients not to commit crimes. See Crystal, supra note 5, at 225-26; Robins, supra note 5, at 409-12. Crystal's views are discussed infra note 82 .

80. Some attorneys reject the notion of a duty to protect third parties. "[I]t is clear that the lawyer for a private party is and should be an officer of the court only in the sense of serving a court as a zealous, partisan advocate in one side of the case before it, and in the sense of having been licensed by the court to play that very role." Legal Times of Wash., June 21, 1982, at 2, col. 3 (quoting T. Koskoff, former President of the American Trial Lawyers Foundation). If an attorney is to function as an advocate, that role inust coine before any role as a watchdog of public safety. But see Frankel, The Search for Truth: An Umpired View, 123 U. PA. L. REv. 1031 (1975); Thurman, Limits to the Adversary System: Interests that Outweigh Confidentiality, 1980 J. LEGAL ProFESSION 5 (both authors argue that truth must outweigh the adversary system). In one sense the attorney must hold his client's confidences inviolate because they are not his to disclose. The client, when he confides in his attorney, still owns the confidence. The attorney is not free to do as he wishes witl the "property" of his client merely because he believes revealing it will do more good than harm. See Landesman, supra note 39, at 775.

Others simply argue that considerations of fairness and balancing are irrelevant. According to this theory the attorney-chent relationship is a personal one, founded on one's inoral right to choose one's friends, therefore

expediency may not compromise the nature of the relation. . . . [T] allow social considerations-even social regulations-to limit and compromise what by hypothesis is an entailment of the original grant of right to the individual is to take away with the left hand what was given with the right. Once the relation has been taken up, it is the client's needs which hold the reins-legally and morally.

Fried, The Lawyer as Friend: The Moral Foundations. of the Lawyer-Client Relation, 85 YALE L.J. 1060, 1077 (1976).

Of course, the lawyer is an autonomous moral unit. Considerations of who "owns" a confidence and moral relationships cannot change that fact. See Landesman, supra note 39, at 777 (as strong as considerations arguing for holding confidences inviolate are, "they cannot be strong enough to remove the hearer's own moral autonomy, his right and duty to act on stronger countervailing reasons"). But see Fried, supra, at 1084 ("one must not transfer uncritically the whole range of personal moral scruples into the arena of legal friendship"). 
tend that disclosure of client confidences is always improper. ${ }^{81}$ Rules that hold client confidences inviolate serve important social interests; these interests are not as clearly advanced when an attorney conceals his knowledge of a client's intended crime. Rules designed to encourage clients to assist their attorneys by providing all of the information necessary for adequate representation need not also protect a client's future criminal activity. Nevertheless, a rule that requires attorneys to preserve their client's confidences in all but the most extreme cases may be necessary to encourage chents to be candid with their attorneys about less extreme but nonethelesss questionable conduct. Preserving the client's confidences not only assists in securing adequate representation but also enhances the possibihty that an attorney may prevent a crime. The importance of a client's perception of fairness should also not be underestimated.

Thus the drafters of a rule governing attorney disclosure of client confidences must accoinodate competing interests: the interest of the client and society in assuring that the client can, and will, honestly disclose his predicament to an attorney, and society's interest in assuring that innocent third parties are not victimized. A rule that makes attorney disclosure of client confidences mandatory in certain circumstances should be assessed in teruns of these competing interests. An ideal rule would prevent all serious crimes that a chent inforns his attorney he intends to commit, yet still protect a client's and society's interests im confidentiahty. Mandatory rules can not reach this goal.

Discretionary rules offer benefits coinparable to mandatory rules, without the attendant harms. Mandatory rules offer hmited benefits because they would be triggered only rarely. Yet, the harms of mandatory disclosure are significant. Attorneys, however, share society's horror of heinous crime; they also appreciate the harms of unwarranted disclosure of client confidences. Thus, so long as rules permit attorneys to exercise reasonable discretion, society can enjoy the benefits of disclosure without suffering the harms that accompany mandatory disclosure.

\section{A. The Benefits and Harms of Mandatory Disclosure.}

A mandatory disclosure obligation might be justified if it saved many lives. Practical considerations suggest that it would not. The discussion draft of the Rules provided that in some situations disclosure

81. Alschuler comes closest to a demand for absolute confidentiality. Alschuler, supra note 74 , at 355 ("the obligation of confidentiality is not a categorical imperative. Hardly anything is. Nevertheless, it comes close . . . .") 
should be mandatory. ${ }^{82}$ But situations where disclosure would be required under such a rule would be rare. Few clients inform their attorneys of their genuine intent to commit a serious crime. Indeed, a mandatory disclosure obligation would likely inake such disclosures even more rare. When chents learn that their secrets are not safe with their attorneys, "[t]lie result inevitably would be tliat clients would withhold the less pleasant and less comfortable trutlis froin tlieir lawyers." 83 One of the uncomfortable truths which chents are likely to withhold is the intention to commit a crime. If clients learn that their lawyers will not respect their secrets, they will no longer divulge them. Therefore, because few clients would inform their attorneys of an intent to kill, a mandatory rule would have tlie potential for saving only an extremely limited number of hives.

The number of intended victims saved by attorneys' revelation is likely to be smaller yet. A inandatory disclosure rule would have to be carefully drafted. The rule would have to define precisely the class of intended crimes that must be disclosed, low certain an attorney inust be that, in the absence of disclosure, the client will commit the crime, and the degree to which the attorney must know that disclosure will prevent the crime. Proving that an attorney should have disclosed information would be inherently difficult. The only witnesses that the attorney had the information will, in the vast majority of cases, be the attorney and the criminal. It is hard to imagine courts accepting arguments froin accused persons that their attorney should have prevented their crimes through disclosure. Thus, unless tlie attorney calls his own conduct into question, whicl seems unlikely, it will be difficult to enforce such a rule. An unenforceable inandatory rule would likely be no more effective in saving lives than would a straigltfforward reliance on discretion.

The limited benefits of a mandatory rule inust be weigled against its potential liarms. A mandatory rule is not likely to save lives that

82. See supra notes $\mathbf{3 2 - 3 4}$ and accompanying text. Commentators argue for mandatory disclosure on varied grounds. Abramovsky argues for mandatory disclosure on the ground that the utmost goal of any society is the preservation of human life. Abramovsky, supra note 5, at 937. Crystal argues, unconvimcingly, that a carefully defined disclosure obligation would not impede communication because communications are already impeded. He makes the standard argument that one should avoid certain harm over speculative benefits. Crystal, supra note 5, at 224. Burt argues that mandatory disclosure would increase trust between attorney and chent by clarifying their relationship. Burt, Confict and Trust Between Attorney and Client, 69 GEO. L.J. 1015, 1015 (1981). See also Callan \& David, supra note 24, at 356.

83. Freedman, The Kutak Model Rules v. the American Lawyer's Code of Conduct, 26 VILL. L. REV. 1165, 1175 (1981). 
would not be saved with a discretionary rule; 84 it does, however, have the potential to cause a great deal of harm. A mandatory disclosure obhigation could even cost lives. Consider the not unlikely case where an attorney with knowledge convinces his client not to cominit further crimes such as killing witnesses or fellow conspirators. With a mandatory disclosure policy, the attorney might never learn of his client's criminal intent and, thus, would never be able to dissuade him from committing the additional crime. The limited benefits to be obtained from a mandatory rule do not outweigh the harms of such a rule. ${ }^{85}$

\section{B. The Alternative of Preserving Attorney Discretion to Disclose.}

Even without a mandatory rule, many hives can be saved. The great majority of attorneys would exercise their discretion to reveal a client's intended crime in the situations in which most agree it is appropriate-those where the client threatens to mjure or kill someone. A mandatory rule could only affect the margim, where agreement regardmg disclosure is not universal. In these cases some practitioners would reveal, while others, confronted with identical facts, would not. This is the only class of cases where a mandatory rule might save lives which the discretionary rule would not. Few lives in this limited class would actually be saved, however.

Some commentators argue that if attorneys have discretion they will play it safe and never disclose what they know. ${ }^{86}$ This argument seems specious. The ever-present possibility of tort liability should convince the attorney to exercise his discretion wisely. Whatever ethical standards the legal profession adopts, these standards will not be bimding on judges im nondisciplinary procedings. The psychiatrist im Tarasoff argued that he was prevented from revealing information by an ethical code. The California court did not accept this argument and imposed tort hability. ${ }^{87}$ 86-88.

84. The abihty of discretionary rules to save hives is discussed infra text accompanying notes

85. Other commentators argue agamst mandatory disclosure. Merton argues against a mandatory standard largely on the impossibility of a lawyer determining whether a client truly intends to carry out his threat. Merton, supra note 10, at 330. Grant argues agamst mandatory disclosure because of the untenable position in which an attorney would be put if the ABA requires disclosure and states retain statutes that prohibit such revelation. Grant, stupra note 54, at 178 (fails to cite state law prohibiting revelation).

86. Crystal argues that because lawyers favor their client's interests a discretionary standard will result in confidentiality. See Crystal, supra note 5, at 227.

87. See supra notes 60-64 and accoinpanying text. 
More importantly, attorneys are trained to exercise discretion and balance competing interests. Perhaps better than anyone else, attorneys understand the value of confidentiality. Attorneys are trained to assist clients im crafting effective strategies for resolving their most delicate problems. In short, most attorneys are quite qualified to make the decisions that a discretionary rule necessitates. ${ }^{88}$ This leads to the conclusion that most of the hives saved by a mandatory rule will also be saved with a discretionary rule.

Assuming that a discretionary rule is chosen, what crimes should an attorney have discretion to reveal? Certainly crimes threatening death or serious bodily mjury should be included. What of serious financial loss? There is probably less reason to reveal financial crimes. It is not too difficult, however, to conceive of financial crimes that warrant revelation. For example, the cartoon scenario of financial wrongdoing that could plunge the global economy into chaos might warrant disclosure. Clearly such a situation is extreinely unlikely. ${ }^{89}$ But if attorneys can discern hife-threatening situations surely they can also know when to reveal the rare financial crime that warrants disclosure.

Attorneys should not be given unbridled discretion. Some crimes can never warrant revelation; a client's intent to jaywalk does not rise to the level of seriousness where revelation should ever be allowed. Between the crimes of jaywalking and inurder a line must be drawn, but where it should be drawn is unclear. A line that defines specific crimes to be revealed seems unwise. One might think crimes of battery should be revealed, yet should a client's intent to slap his spouse be revealed? Cases near the borderline would always arise which should be treated contrary to the rule. The best rule would limit attorney discretion without defining it. A rule that authorized attorneys to reveal plans of "serious crimes" would serve this purpose.

The foregoing analysis suggests that the best rule is the one contamed in the proposed final draft of the Model Rules.90 The rule had no mandatory disclosure provisions. It gave the attorney the discretion to reveal his client's intended serious crimes. At the same time, the discretion vested in the attorney was not so broad as to allow him to reveal all intended crimes. This rule gave attorneys discretion, but only in those situations in which nonrevelation could cause serious harm.

88. See Note, Proposed Model Rule 1.6: Its Effect on a Lawyer's Moral and Ethical Decisions with Regard to Attorney-Client Confidentiality, 35 Baylor L. Rev. 561, $583-84$ (1983).

89. Consider, however, that even the Hunt brothers' effort to corner the market on silver set off a "wild gyration" in the stock inarket. See generally Triggering Turmoil, Wall Street J., March 28,1980 , at 1 , col. 1 .

90. See supra note $40-42$ and accompanying text. 
Such a rule would protect a client's interests in all cases but those where those interests directly infringe on inore inportant interests.

Timothy J. Miller 